\title{
PENGARUH PEMBIAYAAN MUDHARABAH, MUSYARAKAH DAN NON \\ PERFORMING FINANCING TERHADAP RETURN ON ASSET PADA BANK UMUM SYARIAH
}

\author{
Imeh Siti Fatimah ${ }^{1}$ \\ imehsitifatimah16134@student.unsika.ac.id \\ S1 Akuntansi, Universitas Singaperbangsa Karawang \\ Nana Diana ${ }^{2}$ \\ nana.diana@fe.unsika.ac.id, \\ S1 Akuntansi, Universitas Singaperbangsa Karawang
}

\begin{abstract}
Abstrak
Tujuan dari penelitian ini untuk mengetahui hubungan antara pembiayaan mudharabah, musyarakah dan NPF terhadap ROA pada Bank Umum Syariah yang terdaftar di Bank Indonesia periode 2011-2018. Metode yang digunakan adalah deskriptif verifikatif dengan pendekatan kuantitatif yaitu melalui uji asumsi klasik, analisis regresi linier berganda, dan uji hipotesis menggunakan uji-T, uji-F dan uji koefisien determinasi $\left(\mathrm{R}^{2}\right)$. Pengujian data diproses dengan menggunakan perangkat lunak SPSS 22. Sedangkan data yang digunakan yaitu data sekunder dengan tipe data kuantitatif. Populasi penelitian ini berjumlah 14 Bank Umum Syariah dengan metode pengambilan sampel yaitu 4 Bank Umum Syariah. Berdasarkan hasil uji-T, pembiayaan mudharabah berpengaruh positif terhadap ROA. Pembiayaan musyarakah berpengaruh negatif terhadap ROA, dan NPF berpengaruh negatif terhadap ROA. Secara simultan variabel independen berpengaruh terhadap variabel dependen. Sedangkan dari hasil $\mathrm{R}^{2}$ menunjukkan bahwa ROA dipengaruhi oleh pembiayaan mudharabah, musyarakah dan NPF sebanyak 52,3\% dan sisanya 47,7\% dipengaruhi oleh variabel lain di luar penelitian.
\end{abstract}

Kata Kunci : Pembiayaan Mudharabah, Musyarakah, NPF dan ROA

\section{EFFECT OF MUDHARABAH FINANCING, MUSYARAKAH AND NPF ON ROA IN SHARIA COMMERCIAL BANKS}

\section{Abstract}

This study aims to determine the relationship between mudharabah financing, musyarakah and NPF on ROA in Sharia Commercial Banks registered at Bank Indonesian periode 2011-2018. The method used is descriptive verification with a quantitative approach that is through the classic assumption test, multiple linear regression analysis, and hypothesis testing using the Ttest, F-test and the coefficient of determination $\left(R^{2}\right)$ test. Testing data is processed by using SPSS 22 software. While the data used are secondary data with quatitative data types. The population of this study is 14 Sharia Commercial Banks wih a sampling method that is purposive sampling, so that the number of observations obtained is 4 Sharia Commercial Banks. Based on the results of the T-test, mudharabah financing has a positive effect on ROA. Musyarakah financing has a negative effect on ROA, and NPF has a negative effect on ROA. Silmiltaneously all independent variable influences the dependent variable. While the results of The $R 2$ indicate that ROA is influenced by mudharabah financing, musyarakah and NPF by $52,3 \%$ and the remaining $47,7 \%$ is influenced by other variables outside the study.

Keywords: Mudharabah Financing, Musyarakah, NPF and ROA 


\section{PENDAHULUAN}

Pertumbuhan keuangan syariah di tingkat nasional masih belum dapat mengimbangi pertumbuhan keuangan konvensional. Hal ini dapat dilihat dari pangsa pasar (market share) keuangan syariah secara keseluruhan, dari snapshot posisi Desember 2018 yaitu 8,50\%. Jika dilihat dari salah satu sub-sektor jasanya, yaitu perbankan syariah menurut LPKSI 2018, market share perbankan syariah sebesar 5,96\% dari seluruh market share perbankan. Dengan total aset perbankan syariah yaitu senilai Rp 489,69 triliun.

Dalam kegiatannya, bank syariah memiliki banyak akad yang variatif. Bank Umum Syariah saat ini terdiri dari 14 institusi, maka akan terjadi persaingan antar bank syariah baik dalam hal peningkatan pelayanan jasa maupun peningkatan kinerja bank. Oleh karena itu diperlukan penilaian tolak ukur agar mengetahui tingkat kesehatan bank dengan menghitung rasio keuangan yang terdapat dalam publikasi laporan keuangan. Berdasarkan PBI No. 9/1/PBI/2007 Pasal 3, disebutkan bahwa salah satu untuk menilai tingkat kesehatan bank yaitu rentabilitas atau earning. Menurut Surat Edaran No. 9/24/DPbs Tahun 2007 mengatakan jika penilaian rentabilitas digunakan untuk menilai kemampuan bank dalam menghasilkan laba.

Berdasarkan Surat Edaran No. 9/24/DPbs Tahun 2007 yang dikeluarkan oleh Bank Indonesia, penilaian terhadap faktor rentabilitas dilakukan dengan penilaian terhadap komponen-komponen salah satunya yaitu ROA sebagai rasio penunjang. ROA digunakan untuk mengukur efisiensi dan efektivitas perusahaan dalam menghasilkan keuntungan atau profit dengan memanfaatkan aktiva yang dimilikinya. Tingginya ROA mengindikasikan bahwa bank semakin baik dalam mengelola aset yang dimilikinya, agar memperoleh laba (Haryanto 2016). Artinya semakin kecil ROA yang dimiliki bank, maka semakin kurang baik dalam mengukur efektivitas dari keseluruhan operasi perusahaan, begitu pula sebaliknya (Kasmir 2015:202).

Adanya usaha peningkatan kualitas penyaluran aktiva produktif yaitu untuk meningkatkan profitabilitas. Salah satu bentuk penyaluran aktiva produktif perbankan syariah yaitu melalui pembiayaan yang diberikan kepada masyarakat. Menurut Wangsawidjaja (2012:78) bahwa sebagian besar pendapatan bank syariah didapatkan dari imbalan berupa kegiatan usaha pembiayaan. Oleh sebab itu, pembiayaan masih merupakan kegiatan paling dominan pada bank syariah.

Menurut Wangsawidjaja (2012:233-234) bahwa pembiayaan yang diberikan oleh perbankan syariah idealnya lebih banyak berdasarkan akad mudharabah dan musyarakah, hal tersebut dikarenakan sesuai dengan prinsip syariah yaitu profit and loss sharing (PLS). Dengan pembiayaan berdasarkan akad tersebut diharapkan dapat lebih mendorong untuk meningkatkan dalam sektor ekonomi, baik sektor riil (produksi barang) seperti pertanian, pertambangan dan industri ataupun nonriil (nonproduksi) seperti perdagangan dan jasa-jasa.

Pembiayaan akan berpengaruh pada peningkatan profitabilitas suatu bank. Dengan menggunakan profitabilitas sebagai tolak ukur maka akan diketahui sejauh mana bank memperoleh laba untuk meningkatkan keuntungan dari bank tersebut. Ismail (2016:87) menjelaskan manfaat pembiayaan bagi bank salah satunya, yaitu meningkatkan profitabilitas bank. Hal tersebut tercermin pada perolehan laba, dengan adanya peningkatan laba usaha bank menyebabkan profitabilitas bank juga meningkat.

Berdasarkan Peraturan Bank Indonesia mengenai penilaian kualitas aktiva bagi Bank Umum Syariah dan Unit Usaha Syariah yang melaksanakan kegiatan usaha berdasarkan prinsip syariah, kualitas pembiayaan ditetapkan menjadi lima golongan diantaranya yaitu lancar, dalam perhatian khusus, kurang lancar, diragukan dan macet (PBI No. 13/13/PBI/2011).

Disebut pembiayaan bermasalah atau NPF (Non Performing Financing) jika kualitas pembiayaan dari lancar menjadi kurang lancar (golongan III), diragukan (golongan IV) dan macet (golongan V). Apabila pembiayaan menjadi bermasalah artinya telah muncul risiko bagi 
bank syariah, yaitu nasabah belum mampu dalam membayarkembali pokok pembiayaan yang telah disepakati nasabah dalam akad pembiayaan di awal (Wangsawidjaja, 2012:91).

Rasio NPF menggambarkan kinerja perbankan syariah dalam mengatur risiko pembiayaan yang dilakukan. Semakin tinggi rasio NPF artinya kredit macet yang disalurkan semakin tinggi atau manajemen pembiayaan yang dilakukan bank buruk. Begitupun sebaliknya, jika rasio NPF semakin rendah maka kinerja bank semakin baik dalam hal pengelolaan manajemen pembiayaan (Sumarlin 2016). Wangsawidjaja (2012:90) menjelaskan bahwa pembiayaan bermasalah jika dilihat dari segi produktivitasnya, yaitu kemampuan menghasilkan pendapatan bagi bank sudah berkurang bahkan sudah tidak ada lagi. Bagi pihak bank akan mengurangi pendapatan dan besarnya biaya pencadangan yaitu Penyisihan Penghapusan Aktiva (PPA). Dan secara nasional hal tersebut akan mengurangi kontribusi dalam pembangunan dan pertumbuhan ekonomi.

Selain itu terdapat pula penelitian terdahulu yang dilakukan oleh Puteri dkk. (2014) menjelaskan bahwa pembiayaan mudharabah berpengaruh negatif terhadap profitabilitas. Hasil penelitian tersebut berarti setiap terjadi kenaikan pembiayaan mudharabah maka akan menurunkan profitabilitas (ROA). Hasil penelitian yang sama dari Wahyuningsih (2019) menyatakan bahwa hasil pembiayaan mudharabah berpengaruh negatif terhadap profitabilitas.

Penelitian terdahulu lainnya yang menjelaskan keterkaitan antara pembiayaan musyarakah dengan profitabilitas (ROA) adalah penelitian yang dilakukan oleh Nurfajri dan Priyatno (2019) diperoleh yaitu pembiayaan musyarakah berpengaruh negatif terhadap profitabilitas (ROA). Artinya, semakin bertambah volume pembiayaan musyarakah, maka akan menurunkan profitabilitas (ROA) yang diperoleh Bank Umum Syariah. Pernyataan penelitian yang serupa sebagai pendukung yaitu penelitian dari Hasibuan (2019) serta Romdhoni dan Al Yozika (2018).

Beberapa penelitian juga telah dilakukan terkait dengan pengaruh Non Performing Financing (NPF) terhadap Return on Asset (ROA). Yaitu dari hasil penelitian terdahulu menjelaskan bahwa, variabel NPF berpengaruh positif terhadap ROA oleh Yusuf (2017) dan Munir (2018). Hasil penelitian tersebut berarti bahwa setiap terjadi kenaikan NPF, maka ROA yang diperoleh akan naik.

Dengan memperhatikan hal-hal yang telah diidentifikasi di atas, serta adanya perbedaan teori dengan hasil penelitian yang diperoleh. Maka peneliti merasa perlu melakukan penelitian lanjutan.

Tujuan penelitian ini yaitu untuk mengetahui seberapa besar pengaruh pembiayaan mudharabah, musyarakah dan NPF terhadap ROA pada Bank Umum Syariah yang terdaftar di Bank Indoenesia periode 2011-2018. Sehingga rumusan masalah untuk penelitian ini yaitu apakah terdapat pengaruh baik secara parsial dan simultan.

\section{TINJAUAN PUSTAKA}

\section{Return on Asset (ROA)}

Menurut Kasmir (2015:22)ROA menunjukkan hasil atas jumlah aktiva yang digunakan dalam perusahaan. Semakin rendah rasio ROA, maka semakin kurang baik dalam mengukur efektivitas keseluruhan operasi perusahaan. Demikian pula sebaliknya, jika rasio ROA tinggi maka semakin baik dalam mengukur efektivitas keseluruhan operasi perusahaan. Sedangkan Margaretha (2014:18) menyatakan bahwa ROA merupakan rasio yang menunjukkan kemampuan laba atas aktiva yang digunakan.

Dari definisi-definisi tersebut dapat disimpulkan bahwa ROA merupakan rasio yang digunakan untuk menunjukkan kemampuan laba suatu perusahaan. Jika nilai rasio ROA rendah 
maka perusahaan dalam mengelola efektifitas manajemennya kurang baik, begitu pula sebaliknya.

\section{Pembiayaan Mudharabah}

Ismail (2016:140) mengatakan bahwa:

Pembiayaan mudharabah yaitu akad pembiayaan antara bank syariah (shahibul maal) dan nasabah (mudharib) untuk melakukan kegiatan usaha. Bank syariah memberikan dana sebesar $100 \%$ dan nasabah yang menjalankan usaha tersebut. Hasil dari usaha akan dibagi antara bank dan nasabah sesuai dengan nisbah yang telah disepakati saat akad.

Kemudian menurt Ifham (2015:157):

Pembiayaan mudharabah yaitu akad kerja sama antara bank syariah selaku pemilik dana (shahibul maal) dan nasabah (mudharib) yang memiliki keahlian untuk mengelola kegiatan usaha yang halal dan produktif. Hasil dari usaha yang telah dijalankan akan dibagi bersama sesuai dengan nisbah yang telah disepakati.

Berdasarkan dari definisi-definisi di atas, dapat dijelaskan bahwa pembiayaan mudharabah merupakan kegiatan pembiayaan usaha yang produktif dan halal antara bank sebagai pemilik modal dengan memberikan dana $100 \%$ dan nasabah sebagai pengelola usaha yang memiliki keahlian. Keuntungan dibagi berdasarkan nisbah pada awal akad dan telah disepakati.

\section{Pengertian Pembiayaan Musyarakah}

Menurut Ismail (2016:146) bahwa:

Al-Musyarakah yaitu akad dalam bentuk kerja sama antara dua pihak atau lebih untuk menjalankan usaha tertentu, di mana masing-masing pihak memberikan kontribusi dana sebagai modal dengan bagi hasil atas usaha tersebut sesuai kesepakatan atau kontribusi.

Sedangkan, Ifham (2015:165) mengatakan yaitu:

Pembiayaan musyarakah merupakan akad kerja sama antara bank dan nasabah yang mengikatkan diri dalam perserikatan modal dengan jumlah sesuai dengan kesepakatan. Modal yang telah tergabung digunakan untuk mengelola proyek usaha yang sesuai prinsip syariah dan layak. Keuntungan yang diperoleh akan dibagi berdasarkan nisbah yang telah disepakati dalam akad.

Berdasarkan definisi-definisi tersebut dapat dijelaskan bahwa pembiayaan musyarakah adalah akad kerja sama antara dua pihak atau lebih yang memberikan kontribusi dana sesuai kesepakatan untuk menjalankan usaha. Kemudian keuntungan dari usaha akan dibagi berdasarkan ketentuan yang telah disepakati.

\section{Pengertian Non Performing Financing (NPF)}

Menurut Ikatan Bankir Indonesia (2014:285) adalah:

NPF Gross yaitu perbandingan antara pembiayaan bermasalah dengan total pembiayaan dan masing-masing dihitung berdasarkan nilai tercatat dalam neraca secara gross. Adapun yang termasuk dalam pembiayaan bermasalah yaitu pembiayaan dengan kualitas kurang lancar, diragukan, dan macet.

Sedangkan, Karim (2010:76)mengatakan bahwa Non Performing Financing (NPF) merupakan rasio pembiayaan bermasalah yang digunakan untuk mengukur risiko atas pembiayaan yang dilakukan oleh bank syariah.

Berdasarkan definisi-definisi di atas, maka dapat disimpulkan bahwa NPF merupakan pembiayaan bermasalah dengan kategori pembiayaan kualitas kurang lancar, diragukan dan macet untuk mengukur risiko pembiayaan yang dilakukan bank.

\section{Kerangka Pemikiran}


Kerangka berfikir yang telah dibuat agar dapat menggambarkan hubungan antara pembiayaan mudharabah, musyarakah, dan Non Performing Financing (NPF) terhadap Return on Asset (ROA) yaitu sebagai berikut:

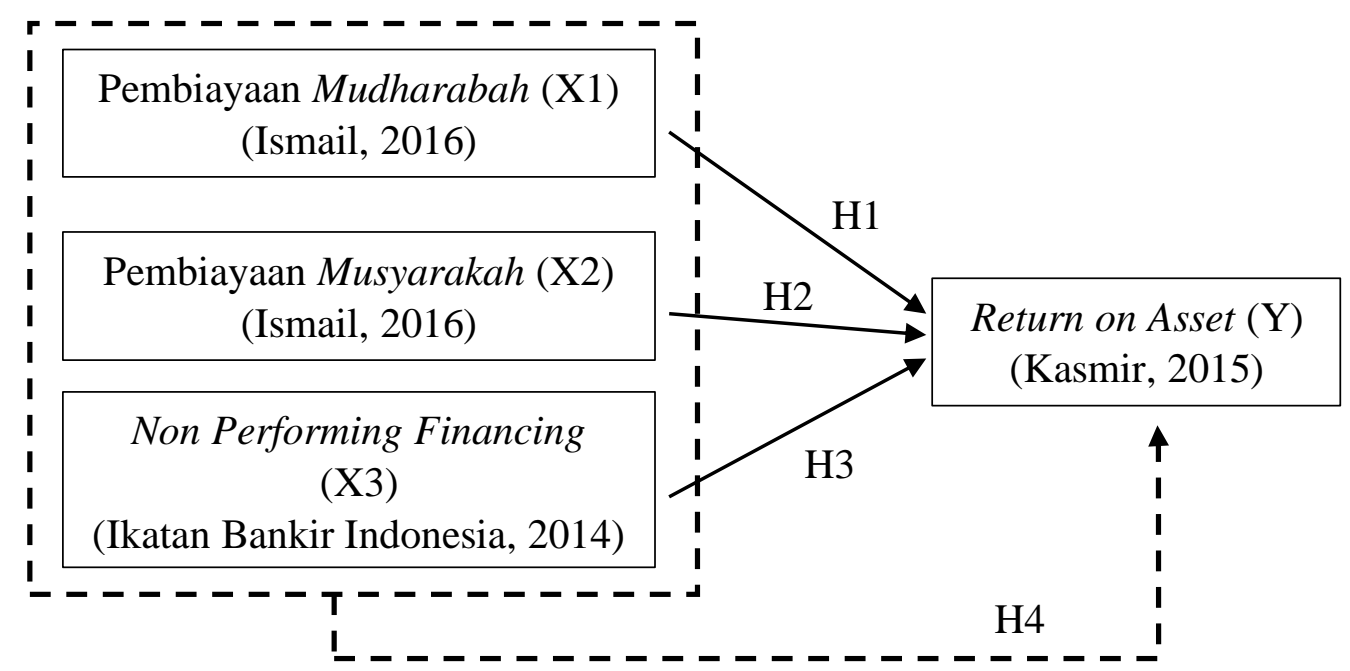

Gambar 1. Paradigma Penelitian

Sumber: Kajian Peneliti, 2020

\section{Hipotesis Penelitian}

Adapun hipotesis penelitian ini yaitu sebagai berikut:

H1 : Terdapat pengaruh pembiayaan mudharabah terhadap Return on Asset (ROA) pada Bank Umum Syariah periode 2011-2018

H2 : Terdapat pengaruh pembiayaan musyarakah terhadap Return on Asset (ROA) pada Bank Umum Syariah periode 2011-2018

H3 : Terdapat pengaruh Non Performing Financing (NPF) terhadap Return on Asset (ROA) pada Bank Umum Syariah periode 2011-2018

H4: Terdapat pengaruh pembiayaan mudharabah, musyarakah dan Non Performing Financing (NPF) terhadap Return on Asset (ROA) pada Bank Umum Syariah periode 2011-2018

\section{METODE}

Metode penelitian yang digunakan adalah deskriptif verifikatif dengan pendekatan kuantitatif. Karena penelitian ini bertujuan untuk mengetahui dan mendeskripsikan seberapa besar pengaruh variabel independen yaitu pembiayaan mudharabah, musyarakah dan Non Performing Financing (NPF) terhadap variabel dependen yaitu Return on Asset (ROA) pada Bank Umum Syariah yang terdaftar di Bank Indonesia. Variabel yang digunakan dalam penelitian terdiri dari data-data berupa angka yang diperoleh dari laporan keuangan, sehingga metode yang digunakan yaitu metode kauntitatif. 


\section{Variabel Penelitian}

\section{Instrumen Penelitian}

Tabel 1. Instrumen Penelitian

\begin{tabular}{|c|c|c|c|}
\hline Variabel & Sub Variabel & Indikator & Skala \\
\hline $\begin{array}{c}\text { Return on } \\
\text { Asset (ROA) }\end{array}$ & $\begin{array}{l}\text { ROA didapat dari laba bersih } \\
\text { yang telah dikurangi bunga dan } \\
\text { pajak dibagi dengan total aset } \\
\text { yang dimiliki oleh perusahaan. }\end{array}$ & $\begin{array}{l}\text { ROA }=\frac{\text { EAIT }}{\text { Total Asset }} \\
(\text { Kasmir, 2015:202) }\end{array}$ & Rasio \\
\hline $\begin{array}{l}\text { Pembiayaan } \\
\text { Mudharabah }\end{array}$ & $\begin{array}{l}\text { Pembiayaan mudharabah diukur } \\
\text { dengan menggunakan indikator } \\
\text { jumlah pembiayaan mudharabah } \\
\text { bersih yang diperoleh dari laporan } \\
\text { keuangan bank syariah. }\end{array}$ & $\begin{array}{l}\text { Jumlah pembiayaan } \\
\text { mudharabah bersih }\end{array}$ & Rasio \\
\hline $\begin{array}{l}\text { Pembiayaan } \\
\text { Musyarakah }\end{array}$ & $\begin{array}{l}\text { Pembiayaan musyarakah diukur } \\
\text { dengan menggunakan indikator } \\
\text { jumlah pembiayaan musyarakah } \\
\text { bersih yang diperoleh dari laporan } \\
\text { keuangan bank syariah. }\end{array}$ & $\begin{array}{c}\text { Jumlah pembiayaan } \\
\text { musyarakah bersih }\end{array}$ & Rasio \\
\hline $\begin{array}{l}\text { Non } \\
\text { Performing } \\
\text { Financing } \\
\text { (NPF) }\end{array}$ & $\begin{array}{l}\text { NPF didapat dari perbandingan } \\
\text { antara pembiayaan bermasalah } \\
\text { dengan total pembiayaan. }\end{array}$ & 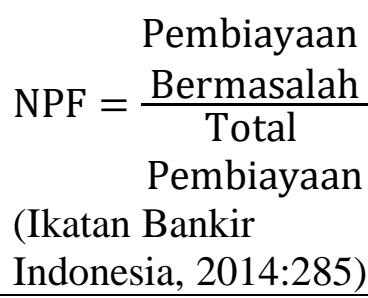 & Rasio \\
\hline
\end{tabular}

Sumber: Kajian Peneliti, 2020

\section{Metode Pengumpulan Data}

\section{Populasi, Sampel dan Teknik Sampling}

Populasi dalam penelitian ini yaitu seluruh Bank Umum Syariah yang terdaftar di Bank Indonesia yaitu berjumlah 14 Bank Umum Syariah. Sedangkan sampel penelitian berjumlah 4 Bank Umum Syariah yang terdaftar di Bank Indonesia, yaitu PT Bank Muamalat Indonesia, PT Bank BRISyariah, PT Bank BNI Syariah dan PT BCA Syariah. Adapun teknik sampling yang digunakan dalam penelitian ini yaitu purposive sampling, peneliti memilih sampel yang dapat memenuhi kriteria-kriteria yang telah ditetapkan oleh peneliti.

Tabel 2. Kriteria Pemilihan Sampel dengan Purposive Sampling

\begin{tabular}{llll}
\hline No. & \multicolumn{1}{c}{ Keterangan } & Jumlah \\
\hline 1 & $\begin{array}{l}\text { Bank Umum Syariah (BUS) yang terdaftar dalam statistik } \\
\text { perbankan syariah. }\end{array}$ & 14 \\
& $\begin{array}{l}\text { Mempublikasi laporan keuangan tahunan secara berkala } \\
\text { selama periode penelitian yaitu tahun 2011-2018 yang } \\
\text { dinyatakan dalam rupiah. }\end{array}$ & \\
\hline
\end{tabular}

Sumber: Kajian Peneliti, 2020 
Tabel 2. (Lanjutan) Kriteria Pemilihan Sampel dengan Purposive Sampling

\begin{tabular}{lll}
\hline No. & Keterangan & Jumlah \\
\hline 3 & $\begin{array}{l}\text { Laporan keuangan selama periode penelitian dapat diunduh } \\
\text { pada website masing-masing bank. }\end{array}$ & (1) \\
4 & $\begin{array}{l}\text { Perusahaan terdaftar di Otoritas Jasa Keuangan (OJK) sebagai } \\
\text { Bank Umum Syariah mulai tahun 2011. }\end{array}$ & (1) \\
5 & $\begin{array}{l}\text { Memiliki kelengkapan data yang akan diteliti sesuai dengan } \\
\text { variabel yang akan diteliti. }\end{array}$ & (4) \\
& $\begin{array}{l}\text { Perusahaan merupakan Bank Umum berdasarkan Kegiatan } \\
\text { Usaha (BUKU) yang telah masuk ke dalam kategori BUKU II }\end{array}$ & \\
6 & $\begin{array}{l}\text { dengan memiliki modal inti yaitu antara 1 hingga kurang dari } \\
5 \text { triliun. }\end{array}$ & \\
& $\begin{array}{l}\text { Bank Umum Syariah tidak mengalami kerugian selama periode } \\
\text { penelitian. }\end{array}$ & \\
Total Bank Umum Syariah yang memenuhi kriteria yang dapat & \\
dijadikan sebagai sampel & 4
\end{tabular}

Sumber: Kajian Peneliti, 2020

\section{Jenis dan Sumber Data}

Jenis data yang digunakan dalam penelitian ini yaitu data sekunder berupa laporan keuangan yang dipublikasi setiap tahunnya oleh masing-masing Bank Umum Syariah yang menjadi sampel dalam penelitian selama kurun waktu 8 tahun yaitu tahun 2011 hingga 2018. Data laporan keuangan tersebut diperoleh dari website resmi yang menjadi sampel dalam penelitian ini.

\section{Teknik Pengumpulan Data}

1. Studi Pustaka

Dengan menggunakan studi pustaka peneliti mendapatkan data terkait penelitian yang akan dilakukan dari sumber tertulis seperti buku, jurnal ilmiah maupun literatur yang diperoleh dari internet sebagai bahan-bahan yang relevan dan mendukung landasan teori dalam menyusun penelitian.

2. Dokumentasi

Dalam penelitian ini dokumentasi berupa laporan keuangan tahunan periode 2011 hingga 2018 Bank Umum Syariah yang telah dipublikasi melalui website resmi masing-masing bank syariah.

\section{Metode Analisis Data}

Metode yang digunakan adalah deskriptif verifikatif dengan pendekatan kuantitatif yaitu melalui uji asumsi klasik, analisis regresi linier berganda, dan uji hipotesis menggunakan uji-T, uji-F dan uji koefisien determinasi $\left(\mathrm{R}^{2}\right)$.

\section{HASIL DAN PEMBAHASAN}

\section{Analisis Deskriptif}

Statistik deskriptif digunakan untuk menggambarkan data dengan statistik yang mengacu pada nilai rata-rata (mean), standar deviasi, nilai minimum dan maksimum dari semua variabel dalam penelitian, yaitu pembiayaan mudharabah, musyarakah, NPF dan ROA selama periode penelitian 2011-2018 yang disajikan sebagai berikut. 
Tabel 3. Analisis Statistik Deskriptif Setiap Variabel

\begin{tabular}{lrrrrr}
\hline & N & Minimum & Maximum & \multicolumn{1}{c}{ Mean } & \multicolumn{1}{c}{$\begin{array}{c}\text { Std. } \\
\text { Deviation }\end{array}$} \\
\hline $\begin{array}{l}\text { Pembiayaan } \\
\text { Mudharabah }\end{array}$ & 32 & 12910 & 2120219 & 784570,94 & 548107,535 \\
$\begin{array}{l}\text { Pembiayaan } \\
\text { Musyarakah }\end{array}$ & 32 & 193776 & 20192427 & 6111603,75 & 6779892,495 \\
NPF & 32 &, 10 & 7,11 & 3,0375 & 2,10600 \\
ROA & 32 &, 08 & 1,54 &, 8728 &, 47910 \\
Valid N (listwise) & 32 & & & & \\
\hline
\end{tabular}

Sumber: Data diolah SPSS, 2020

Beradasarkan tabel 3, pembiayaan mudharabah memiliki mean 784.570,94 yang nilainya lebih besar dari standar deviasi 548.107,535, artinya menunjukkan hasil yang cukup baik yaitu data normal dan tidak menimbulkan bias. Selain itu, nilai minimum pada pembiayaan mudharabah adalah 12.910 dan nilai maksimum yaitu 2.120.219, yang berarti bahwa pembiayaan mudharabah memiliki fluktuasi yang besar.

Pembiayaan musyarakah memiliki mean 6.111.603,75 lebih kecil dari standard deviation yaitu 6.779.892,495, ini berarti menunjukkan hasil yang buruk. Hal tersebut dikarenakan standar deviasi merupakan cerminan dari deviasi yang tinggi, artinya penyebaran data menunjukkan hasil abnormal dan menyebabkan bias. Kemudian diketahui bahwa nilai minimum pembiayaan musyarakah yaitu 193.776 dan nilai maksimum 20.192.427, artinya pembiayaan musyarakah memiliki fluktuasi yang besar.

NPF memiliki mean 3,0375 lebih tinggi dari standar deviasi yaitu 2,10600, sehingga menunjukkan hasil yang cukup baik, data normal dan tidak menimbulkan bias. Selain itu, nilai minimum NPF yaitu 0,10 dan nilai maksimum 7,11 yang berarti bahwa NPF memiliki fluktuasi yang cukup besar. Sedangkan ROA memiliki nilai rata-rata 0,8728 lebih tinggi dari standar deviasi 0,47910 . Hal tersebut menunjukkan hasil yang cukup baik, data penelitian normal dan tidak menimbulkan bias serta nilai minimum ROA yaitu 0,08 dan nilai maksimum 1,54 . Artinya ROA Bank Umum Syariah memiliki fluktuasi yang tidak terlalu besar.

\section{Uji Asumsi Klasik}

1. Uji Normalitas

Tabel 4. Hasil Uji Normalitas

One-Sample Kolmogorov-Smirnov Test

\begin{tabular}{ccc}
\hline & & Unstandardized Residual \\
\hline N & Mean & 32 \\
Normal Parameters $^{\mathrm{a}, \mathrm{b}}$ & Std. &, 0000000 \\
& Deviation &, 31441865 \\
Most Extreme & Absolute &, 095 \\
Differences & Positive &, 068 \\
Test Statistic & Negative &,- 095 \\
Asymp. Sig. (2-tailed) &, 095 \\
\hline
\end{tabular}

Sumber: Data diolah SPSS, 2020 
Nilai signifikan yang diperoleh sebesar 0,200 artinya nilai signifikansi lebih besar dari 0,05 atau $0,200>0,05$. Maka dapat disimpulkan bahwa data berdistribusi normal atau data memiliki model regresi yang baik.

2. Uji Multikolinieritas

Tabel 5. Hasil Uji Multikolinieritas

\begin{tabular}{|c|c|c|c|}
\hline & \multicolumn{3}{|c|}{ Coefficients $^{a}$} \\
\hline & \multirow{2}{*}{ Model } & \multicolumn{2}{|c|}{ Collinearity Statistics } \\
\hline & & Tolerance & VIF \\
\hline \multirow[t]{4}{*}{1} & $($ Constant $)$ & & \\
\hline & Pembiayaan Mudharabah & ,639 & 1,564 \\
\hline & Pembiayaan Musyarakah &, 548 & 1,825 \\
\hline & $\mathrm{NPF}$ &, 538 & 1,859 \\
\hline
\end{tabular}

Sumber: Data diolah SPSS, 2020

Dari hasil pengujian ketahui nilai tolerance masing-masing variabel independen yaitu $>0,10$ dan VIF < 10. Jadi dapat disimpulkan bahwa dalam model ini tidak terjadi multikolinieritas antara variabel independen dalam model regresi.

3. Uji Autokorelasi

Tabel 6. Hasil Uji Autokorelasi

Model Summary ${ }^{\mathrm{b}}$

\begin{tabular}{lrrrrr}
\hline Model & R & R Square & $\begin{array}{c}\text { Adjusted } R \\
\text { Square }\end{array}$ & $\begin{array}{c}\text { Std. Error of the } \\
\text { Estimate }\end{array}$ & $\begin{array}{c}\text { Durbin- } \\
\text { Watson }\end{array}$ \\
\hline 1 &, $755^{\mathrm{a}}$ &, 569 &, 523 &, 33083 & 1,333 \\
\hline
\end{tabular}

Sumber: Data diolah SPSS, 2020

Diketahui bahwa nilai Durbin Watson (DW) yaitu 1,333, di mana nilai DW berada di antara -2 dan +2 atau $-2<1,333<2$. Hal ini membuktikan bahwa dalam model regresi pada data penelitian tidak terjadi autokorelasi atau asumsi bebas korelasi.

4. Uji Heteroskedastisitas

Tabel 7. Hasil Uji Heteroskedastisitas

\begin{tabular}{|c|c|c|c|c|c|c|}
\hline & \multicolumn{6}{|c|}{ Coefficients $^{\mathrm{a}}$} \\
\hline & \multirow[t]{2}{*}{ Model } & \multicolumn{2}{|c|}{$\begin{array}{c}\text { Unstandardized } \\
\text { Coefficients }\end{array}$} & \multirow{2}{*}{$\begin{array}{c}\begin{array}{c}\text { Standardized } \\
\text { Coefficients }\end{array} \\
\text { Beta }\end{array}$} & \multirow[t]{2}{*}{$\mathbf{T}$} & \multirow[t]{2}{*}{ Sig. } \\
\hline & & $\mathbf{B}$ & Std. Error & & & \\
\hline \multirow[t]{4}{*}{1} & (Constant) & ,225 & ,072 & & 3,125 &, 004 \\
\hline & $\begin{array}{l}\text { Pembiayaan } \\
\text { Mudharabah }\end{array}$ & $1,566 \mathrm{E}-8$ & ,000 & ,042 & , 183 &, 856 \\
\hline & $\begin{array}{l}\text { Pembiayaan } \\
\text { Musyarakah }\end{array}$ & $-1,029 \mathrm{E}-8$ & ,000 &,- 341 & $-1,380$ &, 178 \\
\hline & $\mathrm{NPF}$ &, 020 &, 024 & ,204 & ,820 & ,419 \\
\hline
\end{tabular}

Sumber: Data diolah SPSS, 2020

Berdasarkan tabel 7 diketahui bahwa nilai signifikansi masing-masing variabel independen memiliki nilai lebih besar dari 0,05. Maka dapat disimpulkan bahwa tidak terjadi heteroskedastisitas dalam model regresi. 
Analisis Regresi Linier Berganda

Tabel 8. Hasil Uji Analisis Regresi Linier Berganda

\begin{tabular}{|c|c|c|c|c|c|c|}
\hline & \multirow{3}{*}{ Model } & \multicolumn{5}{|c|}{ Coefficients $^{\mathrm{a}}$} \\
\hline & & \multicolumn{2}{|c|}{$\begin{array}{c}\text { Unstandardized } \\
\text { Coefficients }\end{array}$} & \multirow{2}{*}{$\begin{array}{c}\begin{array}{c}\text { Standardized } \\
\text { Coefficients }\end{array} \\
\text { Beta }\end{array}$} & \multirow[t]{2}{*}{$\mathbf{t}$} & \multirow[t]{2}{*}{ Sig. } \\
\hline & & B & Std. Error & & & \\
\hline \multirow[t]{4}{*}{1} & (Constant) & 1,074 &, 114 & & 9,403 & ,000 \\
\hline & $\begin{array}{l}\text { Pembiayaan } \\
\text { Mudharabah }\end{array}$ & $4,587 \mathrm{E}-7$ & ,000 &, 525 & 3,383 & ,002 \\
\hline & $\begin{array}{l}\text { Pembiayaan } \\
\text { Musyarakah }\end{array}$ & $-4,238 \mathrm{E}-8$ & ,000 &,- 600 & $-3,580$ & ,001 \\
\hline & NPF &,- 100 & ,038 &,- 438 & $-2,588$ &, 015 \\
\hline
\end{tabular}

Sumber: Data diolah SPSS, 2020 berikut:

Berdasarkan tabel 8, maka diperoleh persamaan analisis regresi linier berganda sebagai

$$
Y=1,074+0,0000004587 X_{1}-0,00000004238 X_{2}-0,100 X_{3}
$$

Sumber: Kajian peneliti, 2020

Dari persamaan analisis regresi linier berganda tersebut, maka dapat disimpulkan bahwa konstanta memiliki nilai yaitu 1,074 dengan arah positif. Angka tersebut menunjukkan apabila variabel independen konstan atau tidak ada atau bernilai 0 (nol), maka ROA akan mengalami kenaikan sebesar 1,074. Kemudian, pembiayaan mudharabah (X1) memiliki nilai koefisien regresi yang positif yaitu sebesar 4,587 x $10^{-7}$. Nilai koefisien yang positif ini menunjukkan bahwa jika terjadi kenaikan pembiayaan mudharabah sebesar 1, maka tingkat ROA mengalami kenaikan sebesar 4,587 x 10-7. Sedangkan pada variabel pembiayaan musyarakah (X2) memiliki nilai koefisien regresi yang negatif yaitu sebesar $-4,238 \times 10^{-8}$, artinya menunjukkan bahwa jika terjadi kenaikan pembiayaan musyarakah sebesar 1 maka tingkat ROA mengalami penurunan sebesar $-4,238 \times 10^{-8}$. Variabel NPF (X3) memiliki nilai koefisien regresi yang negatif yaitu sebesar $-0,100$, artinya jika terjadi kenaikan sebesar 1 maka tingkat ROA mengalami penurunan sebesar $-0,100$.

\section{Uji Hipotesis}

1. Uji Signifikansi Parameter Individual (Uji Statistik t)

Tabel 9. Hasil Uji Statistik t

\begin{tabular}{|c|c|c|c|c|c|c|}
\hline \multicolumn{7}{|c|}{ Coefficients $^{\mathrm{a}}$} \\
\hline & \multirow[t]{2}{*}{ Model } & \multicolumn{2}{|c|}{$\begin{array}{c}\text { Unstandardized } \\
\text { Coefficients }\end{array}$} & \multirow{2}{*}{$\begin{array}{c}\begin{array}{c}\text { Standardized } \\
\text { Coefficients }\end{array} \\
\text { Beta }\end{array}$} & \multirow[t]{2}{*}{$\mathbf{T}$} & \multirow[t]{2}{*}{ Sig. } \\
\hline & & B & Std. Error & & & \\
\hline \multirow[t]{4}{*}{1} & (Constant) & 1,074 & , 114 & & 9,403 &, 000 \\
\hline & $\begin{array}{l}\text { Pembiayaan } \\
\text { Mudharabah }\end{array}$ & 4,587E-7 & ,000 &, 525 & 3,383 & ,002 \\
\hline & $\begin{array}{l}\text { Pembiayaan } \\
\text { Musyarakah }\end{array}$ & $-4,238 \mathrm{E}-8$ & ,000 &,- 600 & $-3,580$ & ,001 \\
\hline & NPF &,- 100 &, 038 &,- 438 & $-2,588$ &, 015 \\
\hline
\end{tabular}

Sumber: Data diolah SPSS, 2020 
Nilai t tabel dengan tingkat signifikansi $5 \%$ dengan $(0,025 ; 28)$ yaitu sebesar 2,048 . Hasil pengujian pengaruh setiap variabel independen yaitu pembiayaan mudharabah, pembiayaan musyarakah dan NPF terhadap variabel dependen yaitu ROA sebagai berikut:

a. Pengaruh Pembiayaan Mudharabah terhadap ROA

H0 : Tidak terdapat pengaruh pembiayaan mudharabah terhadap Return on Asset (ROA) pada Bank Umum Syariah periode 2011-2018

H1 : Terdapat pengaruh pembiayaan mudharabah terhadap Return on Asset (ROA) pada Bank Umum Syariah periode 2011-2018

Berdasarkan hasil uji diperoleh nilai signifikansi (sig) 0,02 <0,05 dan thitung 3,383 > t tabel 2,048. Maka dapat disimpulkan bahwa H0 ditolak dan H1 diterima yang artinya pembiayaan mudharabah berpengaruh positif terhadap ROA.

b. Pengaruh Pembiayaan Musyarakah terhadap ROA

H0 : Tidak terdapat pengaruh pembiayaan musyarakah terhadap Return on Asset (ROA) pada Bank Umum Syariah periode 2011-2018

H2 : Terdapat pengaruh pembiayaan musyarakah terhadap Return on Asset (ROA) pada Bank Umum Syariah periode 2011-2018

Berdasarkan hasil uji diketahui bahwa nilai signifikansi (sig) 0,01 $<0,05$ dan $\mathrm{t}$ hitung $3,580<\mathrm{t}$ tabel 2,048. Maka dapat disimpulkan bahwa H0 ditolak dan H1 diterima, dengan demikian pembiayaan musyarakah berpengaruh negatif terhadap ROA.

c. Pengaruh NPF terhadap ROA

H0 : Tidak terdapat pengaruh Non Performing Financing (NF) terhadap Return on Asset (ROA) pada Bank Umum Syariah periode 2011-2018

H3 : Terdapat pengaruh Non Performing Financing (NPF) terhadap Return on Asset (ROA) pada Bank Umum Syariah periode 2011-2018

Berdasarkan hasil uji diperoleh nilai signifikansi (sig) 0,015 < 0,05 dan t hitung -2,588 $<\mathrm{t}$ tabel 2,048. Sehingga dapat disimpulkan bahwa H0 ditolak dan H1 diterima, artinya NPF berpengaruh negatif terhadap ROA.

2. Uji Signifikansi Keseluruhan dari Regresi Sampel (Uji Statistik F)

Tabel 10. Hasil Uji Statistik F

\begin{tabular}{ccccccc}
\multicolumn{8}{c}{ ANOVA $^{\mathbf{a}}$} \\
\hline Model & $\begin{array}{c}\text { Sum of } \\
\text { Squares }\end{array}$ & df & $\begin{array}{c}\text { Mean } \\
\text { Square }\end{array}$ & F & $\begin{array}{c}\text { Sig } \\
\text { Sq }\end{array}$ \\
\hline 1 & Regression & 4,051 & 3 & 1,350 & $12,337 \begin{array}{c}, 00 \\
0^{\mathrm{b}}\end{array}$ \\
& Residual & 3,065 & 28 &, 109 & & \\
Total & 7,116 & 31 & & & \\
\hline
\end{tabular}

Sumber: Data diolah SPSS, 2020

Berdasarkan hasil pengujianpada tabel 10, diketahui bahwa nilai $\mathrm{F}$ hitung sebesar 12,337 , diperoleh nilai $F$ tabel yaitu $(2 ; 28)$ sebesar 2,95 . Nilai $F$ hitung dengan $F$ tabel selanjutnya dibandingkan, sehingga didapatkan nilai $\mathrm{F}$ hitung 12,337 > F tabel 2,95 dan nilai signifikansi (sig) 0,000 < 0,05. Maka dapat disimpulkan bahwa H0 ditolak dan H4 diterima, artinya terdapat pengaruh secara simultan pembiayaan mudharabah, musyarakah dan Non Performing Financing (NPF) terhadap Return on Asset (ROA). 
3. Koefisien Determinasi $\left(\mathrm{R}^{2}\right)$

Tabel 11. Hasil Uji Koefisien Determinasi $\left(\mathrm{R}^{2}\right)$

\begin{tabular}{ccccc}
\multicolumn{4}{c}{ Model Summary } \\
\hline Model & R & R Square & Adjusted R Square & Std. Error of the Estimate \\
\hline 1 &, $755^{\text {a }}$ &, 569 &, 523 &, 33083 \\
\hline
\end{tabular}

Sumber: Data diolah SPSS, 2020

Berdasarkan tabel 11, dapat diketahui bahwa niai koefisien determinasi atau adjusted $R$ square yaitu 0,523 atau 52,3\%. Hal ini menunjukkan bahwa 52,3\% dari variabel dependen atau ROA bisa dijelaskan oleh variabel independen yaitu pembiayaan mudharabah, musyarakah dan NPF, sedangkan sisanya sebesar 47,7\% dijelaskan oleh variabel lain di luar penelitian.

\section{PEMBAHASAN}

\section{Pengaruh Pembiayaan Mudharabah terhadap ROA}

Berdasarkan hasil uji t, H0 ditolak dan $\mathrm{H} 1$ diterima yang artinya pembiayaan mudharabah berpengaruh positif terhadap ROA. Nilai koefisien positif ini sesuai dengan teori yang dijelaskan oleh Ismail (2016:87) bahwa semakin tinggi tingkat pembiayaan mudharabah, maka semakin tinggi pula tingkat ROA. Hal tersebut dikuatkan dengan hasil penelitian sebelumnya yang dilakukan oleh Erawati dan Suryanti (2019) yang meneliti mengenai pengaruh produk financing terhadap tingkat profitabilitas, hasilnya pembiayaan mudharabah berpengaruh positif terhadap profitabilitas. Penelitian lainnya yang mendukung yaitu dari Medyawati dan Yunanto (2018) yang menyatakan bahwa profitabilitas dipengaruhi oleh bagi hasil.

\section{Pengaruh Pembiayaan Musyarakah terhadap ROA}

Berdasarkan hasil uji t, $\mathrm{H} 0$ ditolak dan $\mathrm{H} 2$ diterima, dengan demikian pembiayaan musyarakah berpengaruh negatif terhadap ROA. Artinya setiap terjadi kenaikan pembiayaan musyarakah, maka akan menurunkan nilai ROA. Hal ini disebabkan pada pembiayaan musyarakah, masing-masing pihak yaitu bank syariah dan nasabah memberikan kontribusi dana sehingga memiliki risiko yang cukup besar dan berpengaruh terhadap ROA. Serta dapat pula disebabkan pada pembiayaan musyarakah yang kurang baik, sehingga kualitas pembiayaan kurang optimal dan bagi hasil yang diterimapun menurun.

Adapun hasil penelitian terdahulu yang mendukung hasil penelitian ini, yaitu penelitian dari Nurfajri dan Priyanto (2019) menyatakan bahwa pembiayaan musyarakah berpengaruh negatif terhadap ROA. Penelitian lainnya yang mendukung yaitu dari Hasibuan (2019) serta Romdhoni dan Al Yozika (2018) yang menunjukkan bahwa pembiayaan musyarakah berpengaruh negatif terhadap profitabilitas.

\section{Pengaruh NPF terhadap ROA}

Berdasarkan hasil uji t, H0 ditolak dan H3 diterima, artinya NPF berpengaruh negatif terhadap ROA. Nilai koefisien negatif ini sejalan dengan teori yang dijelaskan oleh Wangsawidjaja (2012:90), bahwa semakin rendah nilai NPF berarti semakin baik nilai produktivitas bank dalam menghasilkan pendapatan.

Hasil penelitian ini didukung oleh penelitian sebelumnya, yaitu penelitian dari Muhammad Syakhrun (2019) yang mengatakan NPF berpengaruh negatif terhadap profitabilitas. Hasil tersebut menjelaskan jika NPF semakin tinggi, maka kualitas pembiayaan bank semain buruk karena jumlah pembiayaan bermasalah semakin besar. Dengan demikian, profitabilitas bank pun akan menurun karena adanya peningkatan biaya cadangan aktiva produktif. 


\section{Pengaruh Pembiayaan Mudharabah, Musyarakah, NPF terhadap ROA}

Berdasarkan hasil pengujian dari variabel pembiayaan mudharabah, musyarakah dan NPF secara simultan terhadap ROA, dapat diketahui nilai F hitung 12,337 > F tabel 2,95 dan nilai signifikansi (sig) 0,000 < 0,05. Maka dapat disimpulkan bahwa H0 ditolak dan H4 diterima, artinya terdapat pengaruh secara simultan pembiayaan mudharabah, musyarakah dan NPF terhadap ROA pada Bank Umum Syariah periode 2011-2018.

Sedangkan dari hasil uji koefisien determinasi $\left(\mathrm{R}^{2}\right)$ di atas, diketahui bahwa nilai koefisien determinasi atau adjusted $R$ square yaitu 0,523 atau sebesar 52,3\%. Hal ini menunjukkan bahwa 52,3\% dari variabel dependen atau ROA bisa dijelaskan oleh variabel independen yaitu pembiayaan mudharabah, musyarakah dan NPF, sedangkan sisanya sebesar $47,7 \%$ dijelaskan oleh variabel lain atau faktor lain di luar penelitian.

Penelitian ini didukung penelitian yang dilakukan oleh Daniel Yusuf, dkk (2019) yang menyatakan bahwa secara simultan pembiayaan mudharabah, musyarakah dan NPF berpengaruh terhadap ROA.

\section{SIMPULAN}

Berdasarkan penelitian yang telah dilakukan tentang pengaruh pembiayaan mudharabah, musyarakah dan NPF terhadap ROA pada Bank Umum Syariah yang terdaftar di Bank Indonesia periode 2011-2018, dapat disimpulkan yaitu pembiayaan mudharabah secara parsial berpengaruh positif terhadap ROA pada Bank Umum Syariah yang terdaftar di Bank Indonesia priode 2011-2018. Sedangkan, pembiayaan musyarakah dan NPF secara parsial berpengaruh negatif terhadap ROA pada Bank Umum Syariah yang terdaftar di Bank Indonesia periode 2011-2018. Dan secara simultan pembiayaan mudharabah, musyarakah dan NPF memiliki pengaruh terhadap ROA pada Bank Umum Syariah yang terdaftar di Bank Indonesia periode 2011-2018.

\section{BUKU}

\section{DAFTAR PUSTAKA}

Ifham, Ahmad. 2015. Ini Lho Bank Syariah. Jakarta: PT Gramedia Pustaka.

Ikatan Bankir Indonesia. 2014. Memahami Bisnis Bank Syariah. Jakarta: PT Gramedia Pustaka Utama.

Ismail. 2016. Perbankan Syariah. Jakarta: Prenada Media.

Karim, Adiwarman A. 2010. Bank Islam Analisis Fiqih Dan Keuangan. Jakarta: PT RajaGrafindo Persada.

Kasmir. 2015. Analisis Laporan Keuangan. Jakarta: PT RajaGrafindo Persada.

Margaretha, Farah. 2014. Dasar-Dasar Manajemen Keuangan. Jakarta: Dian Rakyat.

Z, A. Wangsawidjaja. 2012. Pembiayaan Bank Syariah. Jakarta: PT Gramedia Pustaka Utama. JURNAL

Erawati, Teguh dan Suryanti. 2019. Pengaruh Produk Financing terhadap Tingkat Profitabilitas pada Bank Umum Syariah di Indonesia Periode 2015-2018. Jurnal Ilmiah Akuntansi Dan Humanika 9(3):256-66.

Haryanto, Sugeng. 2016. Profitability Identification Of National Banking Through Credit, Capital, Capital Structure, Efficiency, and Risk Level. JDM: Jurnal Dinamika Manajemen 7(1):11-21.

Hasibuan, Faisal Umardani. 2019. Analisis Pengaruh Pembiayaan Murabahah, Mudharabah, dan Musyarakah terhadap Return on Asset Studi Kasus Pada PT Bank Muamalah Indonesia TBK. Periode 2015-2018. Human Falah 6(1):19-36. 
Medyawati, Henny dan Muhamad Yunanto. 2018. The Effects of FDR, BOPO, and Profit Sharing on the Profitability of Islamic Banks in Indonesia. International Journal of Economics, Commerce and Management VI(5):811-25.

Munir, Misbahul. 2018. Analisis Pengaruh CAR, NPF, FDR dan Inflasi terhadap Profitabilitas Perbankan Syariah di Indonesia. IHTIFAZ: Journal of Islamic Economics, Finance and Banking 1(1\&2):88-98.

Nurfajri, Faiz \&. Toni Priyanto. 2019. Pengaruh Murabahah, Musyarakah, Mudharabah , dan Ijarah terhadap Profitabilitas Bank Umum Syariah di Indonesia. Jurnal Monex 8(2):1-18.

Puteri, Deasy Rahmi, Inten Meutia \&. Emylia Yuniartie. 2014. Pengaruh Pembiayaan Mudharabah, Musyarakah, Murabahah, Istishna dan Ijarah Terhadap Profitabilitas pada Bank Umum Syariah. Akuntabilitas: Jurnal Penelitian Dan Pengembangan Akuntansi $8(1): 1-24$.

Romdhoni, A. Haris \&. Ferlangga Al Yozika. 2018. Pengaruh Pembiayaan Mudharabah, Musyarakah dan Ijarah terhadap Profitabilitas Bank Muamalat Indonesia. JIEI: Jurnal Ilmiah Ekonomi Islam 4(03):177-86.

Sumarlin. 2016. Analisis Pengaruh Inflasi, CAR, FDR, BOPO, dan NPF terhadap Profitabilitas Perbankan Syariah. ASSETS 6(2):296-313.

Syakhrun, Muhammad, Abi Asmin \&. Anwar. 2019. Pengaruh CAR, BOPO, NPF dan FDR terhadap Profitabilitas pada Bank Umum Syariah di Indonesia. BJRM: Bongaya Journal of Research in Management 2(1):1-10.

Wahyuningsih, Indah. 2019. "Menakar Dampak Pembiayaan Mudharabah dan Musyarakah terhadap Profitabilitas Return on Assets PT. Bank Muamalat Indonesia Tbk." AlMashrafiyah: Jurnal Ekonomi, Keuangan, Dan Perbanakn Syariah 3(1):15-26.

Yusuf, Daniel, Hamdani \&. Kholilul Kholik. 2019. The Effect of Buy and Sell Financing (Murabahah) , Profit Share Financing (Mudarabah), Equity Capital Financing (Musyarakah) and Non-Performing Financing Ratio on Profitability Level of Sharia Commercial Banks in North Sumatera. BioHS-Journal: Britain International of Humanities and Social Sviences Journal 1(1):81-88.

Yusuf, Muhammad. 2017. Dampak Indikator Rasio Keuangan terhadap Profitabilitas Bank Umum Syariah di Indonesia. Jurnal Keuangan Dan Perbankan 13(2):141-51.

\section{SUMBER HUKUM :}

Peraturan Bank Indonesia No. 13/13/PBI/2011 tentang Penilaian Kualitas Aktiva bagi Bank Umum Syariah dan Unit Usaha Syariah

Peraturan Bank Indonesia No.9/1/PBI/2007 tentang Sistem Penilaian Tingkat Kesehatan Bank Berdasarkan Prinsip Syariah

Surat Edaran No. 9/24/DPbs Tahun 2007 tentang Sistem Penilaian Tingkat Kesehatan Bank Umum Berdasarkan Prinsip Syariah

\section{WEBSITE}

https://www.bankmuamalat.co.id/. Diakses pada tanggal 22 Februari 2020

https://www.bcasyariah.co.id/. Diakses pada tanggal 01 Maret 2020

https://www.bi.go.id/. Diakses pada tanggal 10 Maret 2020

https://www.bnisyariah.co.id/. Diakses pada tanggal 25 Februari 2020

https://www.brisyariah.co.id/. Diakses pada tanggal 24 Februari 2020 